\title{
Lead Reservoirs and Metallization in Nigeria: Example of a Contrasting Geological Terrains
}

\author{
Silas Dada1, Onema Adojoh",*, Adisa Rahaman³, Ibrahim Garba ${ }^{4}$ \\ ${ }^{1}$ Kwara State University, Department of Geology, Malete, P.M.B 1530 Ilorin, Nigeria \\ ${ }^{2}$ University of Liverpool, School of Environmental Sciences, Department of Geography, Earth and Ecological Sciences, Roxby \\ Building, Room 805 B, L69 7ZT, UK \\ ${ }^{3}$ Obafemi Awolowo University, Department of Geology, Ile-Ife, Nigeria \\ ${ }^{4}$ Kano State University of Science and Technology, Department of Geology, P.M.B 3244, Wudil, Nigeria \\ *Corresponding author: onema.adojoh@liverpool.ac.uk
}

Received March 29, 2015; Revised April 07, 2015; Accepted April 13, 2015

\begin{abstract}
Whole rock and mineral extracts from Nigerian goldfields of late Proterozoic age are significantly more radiogenic than those from the much younger Mesozoic lead-zinc mineralization in the Benue Trough, their common formation by hydrothermal processes notwithstanding. Their marked contrasts in lead isotope compositions can be attributed to differences in source reservoirs, structural settings and geological history rather than their age of mineralization. The Mesozoic sulphides have a remarkable uniformly unradiogenic composition for their age, placing the deposits in the lower crustal geotectonic environment that indicate a source of much lower $\mu$. In contrast, mineral extracts from the southwestern and northwestern Nigeria gold deposits show increasingly radiogenic composition and plot in the mixed and upper crustal geotectonic fields respectively, typical of sources enriched in $\mathrm{U} / \mathrm{Pb}$ and $\mathrm{Th} / \mathrm{Pb}$ ratios, with clear indication of larger upper crustal reservoir of much higher $\mu$. Therefore, exploration efforts may need to emphasize near-source mineralization prospects of low radiogenic $\mathrm{Pb}$ composition for economic deposits.
\end{abstract}

Keywords: lead reservoirs, metallization, $\mathrm{U} / \mathrm{Pb}$ and $\mathrm{Th} / \mathrm{Pb}$ ratios, Benue trough, economic deposits

Cite This Article: Silas Dada, Onema Adojoh, Adisa Rahaman, and Ibrahim Garba, "Lead Reservoirs and Metallization in Nigeria: Example of a Contrasting Geological Terrains." Journal of Geosciences and Geomatics, vol. 3, no. 2 (2015): 28-36. doi: 10.12691/jgg-3-2-1.

\section{Introduction}

Auriferous fields within the Gondwana continental landmass in Nigeria and NE Brazil include Archaean to
Early Proterozoic crystalline cores of the West African and Congo cratons, the Pan-African mobile belt between the cratons and their Phanerozoic cover rocks (Figure 1) (Dada, 1995).

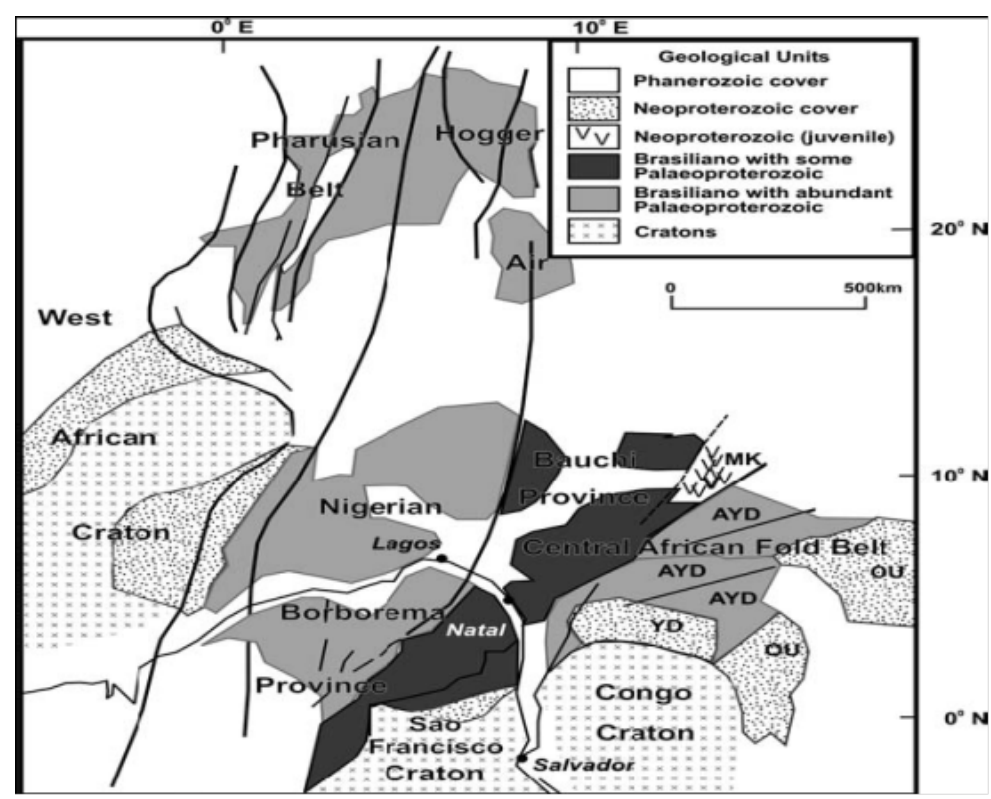

Figure 1. Pre-drift Proterozoic belts and their Phanerozoic cover rocks between the cratons (Dada 2008) 
The heterogeneous nature of the late Proterozoic continental collision thermotectonic event, particularly its all-pervasive structural and metamorphic obliteratory effect on the pre-existing older rocks, has necessitated the deployment of several approaches in the elucidation of its pre-drift evolution (Dada, 1989). Younger Phanerozoic cover rocks also host hydrothermally processed mineralization whose mineralizing fluids are related to deep seated fractures in older crystalline rocks (1995, Dada).

There are no reliable isotopic ages for Nigerian gold deposits but structural correlations suggest that gold mineralizing events are intimately related to the N-S trending semi-ductile to brittle strike-slip faults formed during late Proterozoic orogen-parallel wrenching (Garba, 2000). The kinematics indicate dextral and sinitral movements that are coeval with the formation of sulphidebearing quartz veins and the late phase Pan-African Sn$\mathrm{Nb}$-Ta bearing pegmatites. In this study, Plumbotectonics modeling, which appears to be a function of the tectonothermal age of the crust (Rudnick \& Goldstein, 1990), is used in constraining the $\mathrm{Pb}$ isotopic reservoirs of the diachronous deposits; particularly because the ${ }^{206} \mathrm{~Pb} /{ }^{204} \mathrm{~Pb}$ and ${ }^{208} \mathrm{~Pb} /{ }^{204} \mathrm{~Pb}$ ratios are indicative parameters for the source of the metals. The less radiogenic $\mathrm{Pb}$ isotopic composition of much younger Mesozoic Pb-Zn deposits of the Benue Trough (Maurin \& Lancelot, 1987) contrasts the radiogenic $\mathrm{Pb}$ data presented herein from much older Upper Proterozoic metasedimentary terrains.

\section{Geological Setting}

Overlying the Archaean gneissic complex in Nigeria are widespread Proterozoic metasediments, which include variable volcanic components, well developed as elongated $\mathrm{N}-\mathrm{S}$ trending belts in the western half of Nigeria. There are no affirmative ages of formation for metasediments in Nigeria and the Borborema province of NE Brazil. Inferred depositional ages for the Palaeoproterozoic series in these areas straddle from 2.2 to $2.0 \mathrm{Ga}$ and predate the 1.9-1.8 Ga igneous activities (Grant, 1970; Rahaman \& Emofurieta, 1983; Rahaman \& Lancelot, 1984; Jardim de Sa et al., 1987; Annor, 1995; Neves et al., 2006). In addition to the well developed medium to high grade schists, the Neoproterozoic series of mainly low grade, weakly deformed metasediments occur in association with the thermal aureole of Pan-African granitoids and show upper greenschist to low pressure amphibolite facies metamorphism. More recent work on the same series in NE Brazil (Van Schmus et al., 2003; Neves et al., 2009), their structural relationships with Pan-African granitoids as well as their unequivocal reworking suggest a Neoproterozoic age of deposition. Gold and other metallic deposits occur in these rocks in Brazil and Nigeria and the Pan African is widely accepted as the minimum age of gold and associated mineralization in this belt.

Neoproterozoic granitoids in Nigeria consist of several contemporaneous petrologic groups. Their formation ages are well constrained between 640 and 580 Ma (Tubosun et al., 1984; Dada \& Respaut, 1989; Dada et al., 1989; Rahaman et al., 1991). Pb isotope geochemistry on whole rocks and feldspars collected from plutons in north central Nigeria have been used to describe the evolution of the magmatic processes involved in their formation and the $\mathrm{Pb}$ reservoirs defined (Dada et al., 1995). The well defined Pan-African deformation pattern in the Nigerian schist belts has been related to gold and associated mineralization.

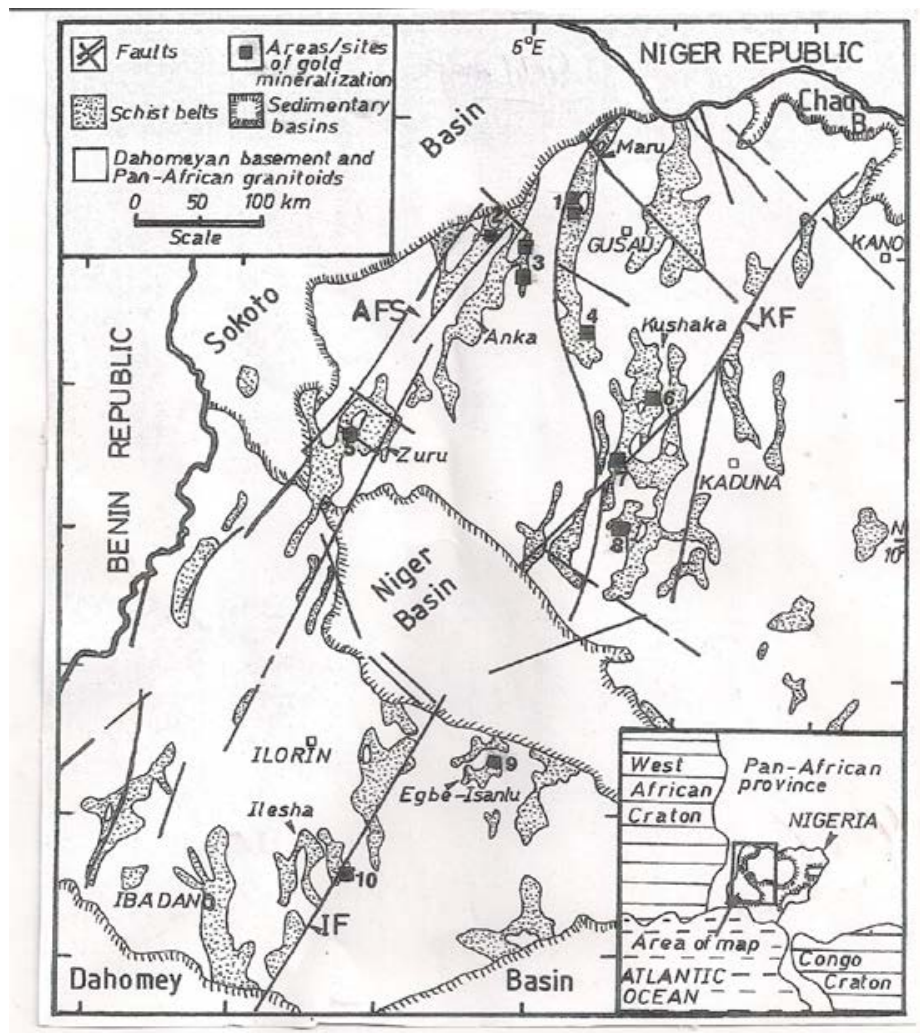

Figure 2a. Major areas of gold mineralization in the schist belts of western half of Nigeria. AFS Anka Fault System, KF Kalangai Fault, IF Ifewara Fault. 1 Maru, 2 Kwali, 3 Anka (Zuzurfa, Kuba), 4 Malele, 5 Bin Yauri, 6 Tsohon Birnin Gwari, 7 Kwaga, 8 Gurmana, 9 Okolom-Dogondaji, 10 Iperindo, after (Garba 2003) 


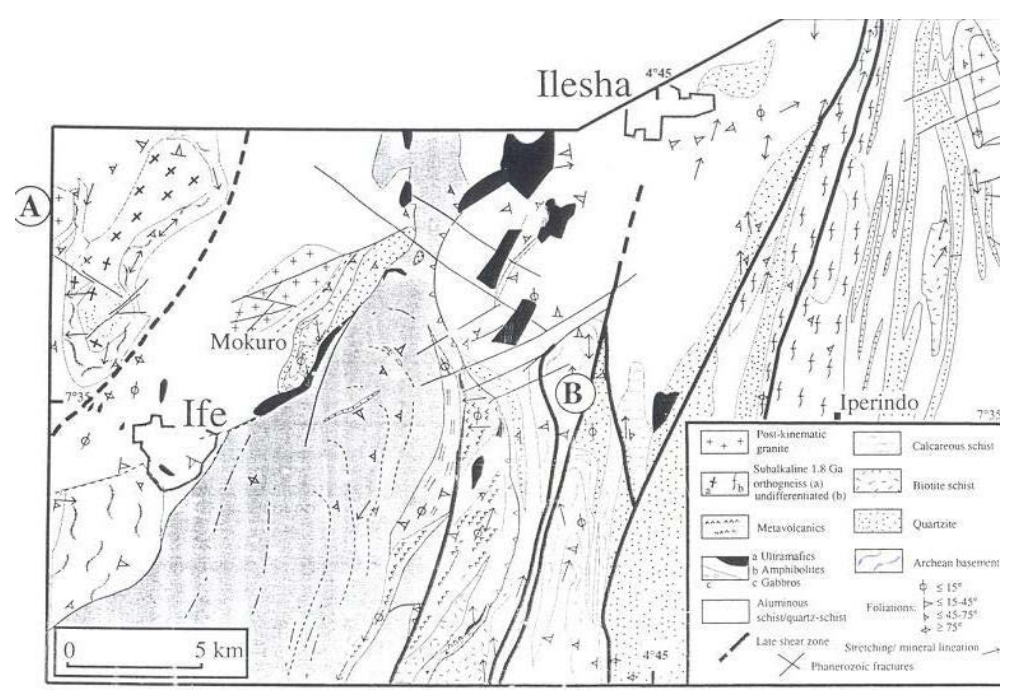

Figure 2b. Geological map of Ife-Ilesha schist belt showing the location of Iperindo goldfield (Caby \& Boesse 2001).

\subsection{Mesozoic Sediments}

Mesozoic sediments of Late Aptian to Maastritchian age are well developed in the Benue Trough subsequent to the opening of the south Atlantic. The coastal basin that developed in the South America and African landmasses developed a triple junction in the Guinean region with the formation of inland basin along the Benue with lead, sphalerite, brine and other associated mineralization. The origin and material sources of the widespread mineralization has been a subject of intense study and research. Available $\mathrm{Pb}-\mathrm{Pb}$ isotope data is used in our comparative analysis with similar data from other geological terrains in Nigeria. We discuss our present understanding of metal sources in Nigeria; using new and pre-existing $\mathrm{Pb}-\mathrm{Pb}$ data of ore pyrite, galena and chalcopyrite of the quartz-sulphide-gold veins from deposits in the Nigerian schist belts and the galenasphalerite deposits of the Benue Trough (Figure 2 \& Figure 3 ) in order to constrain the local source rocks of lead, identify the isotopic composition of the main $\mathrm{Pb}$ reservoirs, and by analogy, of the mineralization.

\section{Methodology}

\subsection{Isotopic Data}

$\mathrm{Pb}$ isotope data include recent analyses on sulphides from northwestern Nigerian goldfields carried out at the Canadian Activation Laboratories, existing data of Maurin \& Lancelot (1987) on lead-zinc mineralization from the Benue Trough, with comparisons using granitic rocks from northern Nigeria (Dada et al., 1995), Iperindo goldfield Oyinloye, 2006) and aplites from Ibadan (Oversby, 1975).

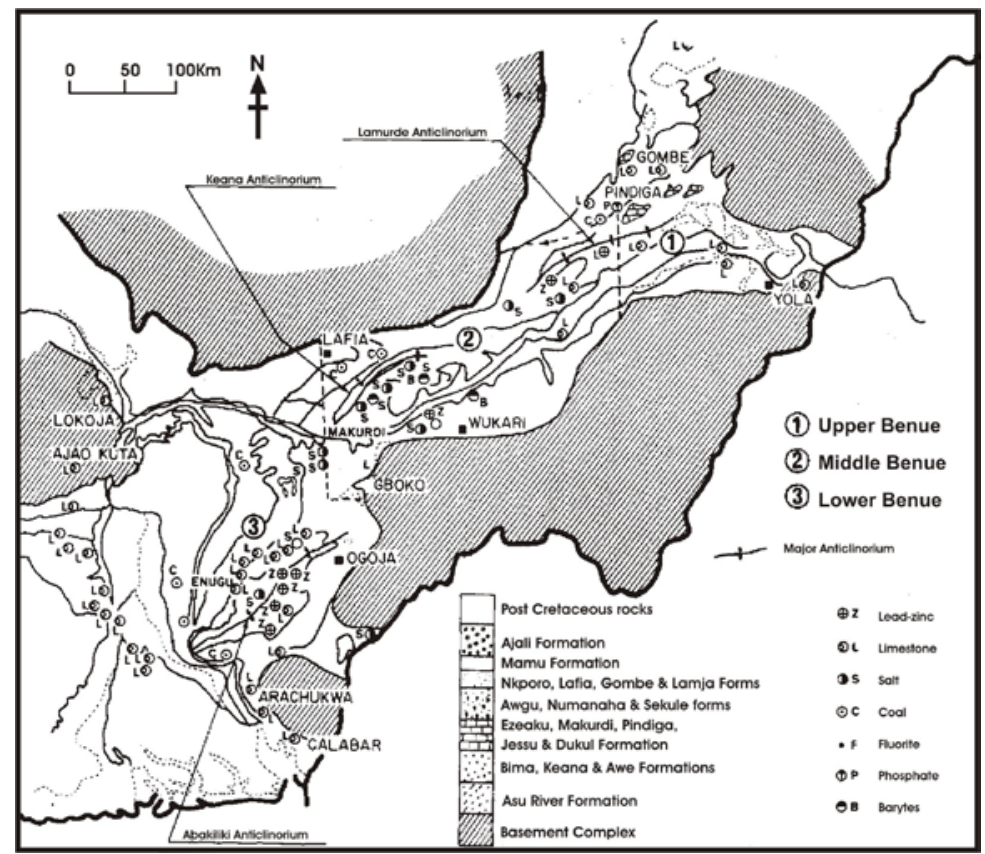

Figure 3. Mesozoic Pb-Zn and related mineralization in the Nigerian Benue Trough, after (Burke et al. 1972)

\subsection{Identification of Source End-members}

Lead in sulphides of most ore deposits have been derived from underlying basement rocks and they give information on age and average $\mathrm{Pb}$ composition of such underlying basement and their constituents (1990, Rudnick). Nigeria consists of an amalgam of contrasted terrains with well developed metasedimentary rocks known as schist belts to the west and widespread 
crystalline, essentially granitic rocks under Mesozoic to Tertiary cover rocks to the east (1984, Rahaman). The entire Nigerian basement has been reworked during thermotectonic Pan-African orogeny (600 Ma), during which prominent strike-slip shears developed along-strike extensions southwards into the Borborema province of northeast Brazil (Dada, 2008). These two provinces obviously have several geological similarities including tectonic, mineralization, age, etc; parameters that are germane to our discussion in this study. Field evidence indicates that both the Proterozoic vein-gold mineralization in the metasediments and the Mesozoic galena-sphalerite and associated vein mineralizations in the Benue Trough are epigenetic (Ogunleye, 2003; Offodile, 1980; Maurin \& Lancelot, 1987). Large mineralized veins are not common in the Nigerian Precambrian and are represented only by far-between quartz-sulphide gold and cassiterite-tantalite-bearing pegmatites and quartz veins that contain scheelite in association with talc schists in central Nigeria. On the other hand, the Nigerian Mesozoic Benue Trough is well endowed with solid minerals of great diversity, including metallic and industrial minerals. In general, there is direct correspondence between the $\mathrm{Pb}$ composition of the source rock and the ore deposits. We have therefore used the lead isotope compositions in $\mathrm{Pb}-\mathrm{Pb}$ isotope diagrams (Figure 4, Figure 5, Figure 6 \& Figure 7) of K-feldspars from basement rocks and sulphides from ore deposits to suggest possible geodynamic reservoirs.

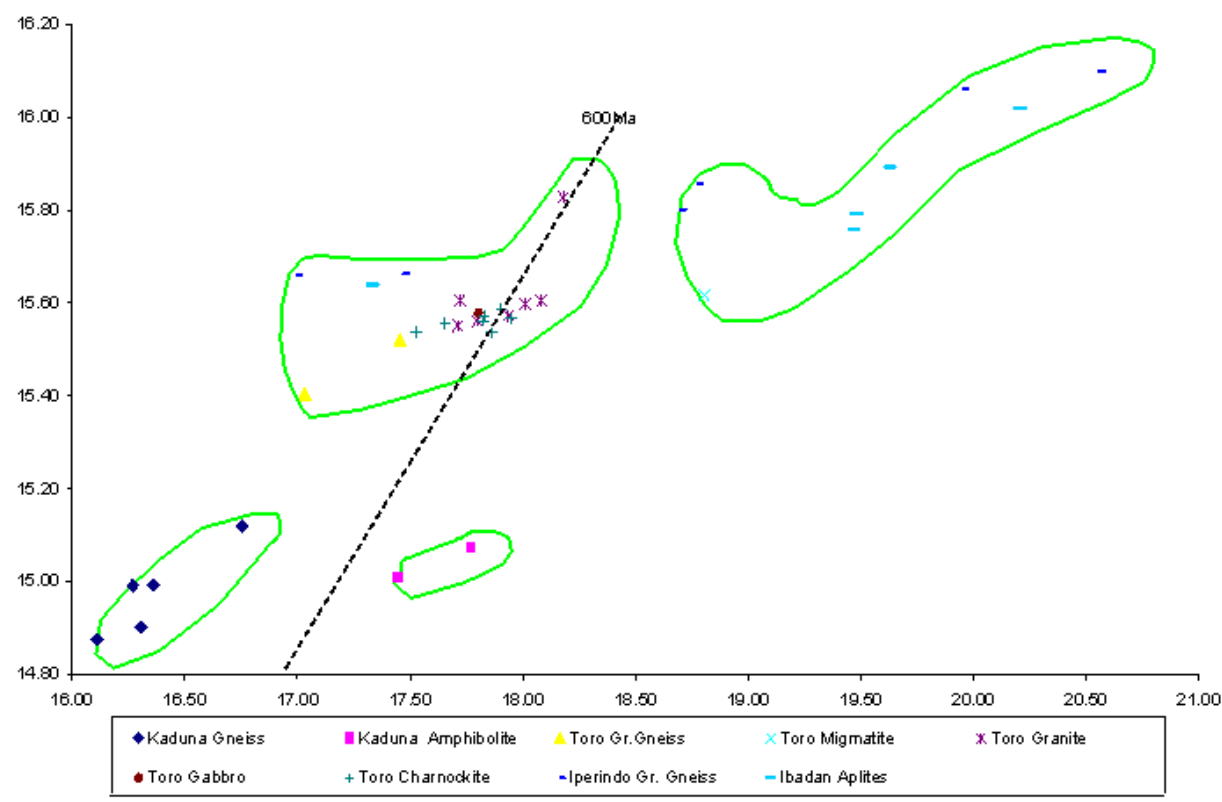

Figure 4a. ${ }^{207} \mathrm{~Pb} /{ }^{204} \mathrm{~Pb} v{ }^{206} \mathrm{~Pb} /{ }^{204} \mathrm{~Pb}$ of various rocks in Nigeria with the $600 \mathrm{Ma}$ reference isochron

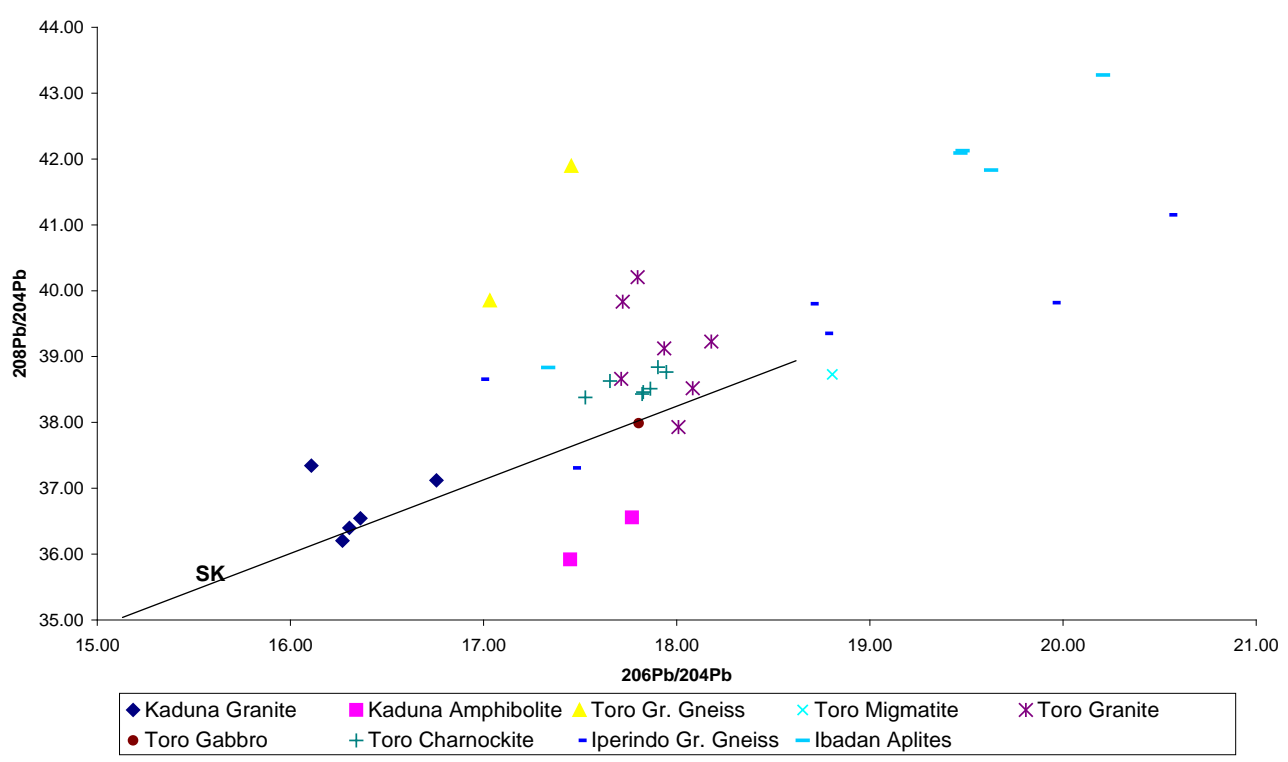

Figure 4b. ${ }^{208} \mathrm{~Pb} /{ }^{204} \mathrm{~Pb} v{ }^{206} \mathrm{~Pb} /{ }^{204} \mathrm{~Pb}$ of various rocks in Nigeria with the average growth curve of Stacey \& Kramers, SK (1975)

\subsection{Lead Isotope Data}

On ${ }^{207} \mathrm{~Pb} /{ }^{204} \mathrm{~Pb}$ vs ${ }^{206} \mathrm{~Pb} /{ }^{204} \mathrm{~Pb}$ and ${ }^{208} \mathrm{~Pb} /{ }^{204} \mathrm{~Pb} \quad$ vs ${ }^{206} \mathrm{~Pb} /{ }^{204} \mathrm{~Pb}$ diagrams (Figure 4, Figure 5, Figure 6, Figure 7), the lead isotope data for whole rocks and mineralization plot in a series of echelon clusters along linear arrays. Geographical trends can be contoured (Isoplumbs) with increasing radiogenic whole rock lead to the southwest (Figure 4). Apart from those from northwest goldfields, all 
mineral extracts including K-feldspars plot along a linear array, regardless of the age of their host rocks. The only exception from northwest gold is the galena sample from Malele. This most probably implies that all other deposits were derived from source rocks of the same age that had initial $\mathrm{Pb}$ isotopic compositions similar to that preserved in Pan-African feldspars. When samples from NW goldfields are exempted, the slope of the linear array (0.1785) on the ${ }^{207} \mathrm{~Pb} /{ }^{204} \mathrm{~Pb}$ vs ${ }^{206} \mathrm{~Pb} /{ }^{204} \mathrm{~Pb}$ gives an approximate age of 2.01Ga. This is likely to be a crustal residence average mixing age indicative of older source for both sulphide and K-fedspar lead. However the tectonic reservoirs involved have remained undefined. This has implications for exploration.

Table 1. Pb isotope composition of basement rocks from northern Nigeria

\begin{tabular}{|c|c|c|c|}
\hline Sample (NG) & ${ }^{206} \mathbf{P b} /{ }^{204} \mathbf{P b}$ & ${ }^{207} \mathrm{~Pb} /{ }^{204} \mathrm{~Pb}$ & ${ }^{208} \mathbf{P b} /{ }^{204} \mathrm{~Pb}$ \\
\hline \multicolumn{4}{|l|}{ Kaduna gneisses } \\
\hline 301 & 16.305 & 14.901 & 36.398 \\
\hline 304 & 16.362 & 14.992 & 36.543 \\
\hline 306 & 16.109 & 14.875 & 37.344 \\
\hline 307 & 16.270 & 14.992 & 36.204 \\
\hline 309 & 16.756 & 15.119 & 37.121 \\
\hline \multicolumn{4}{|c|}{ Kaduna amphibolites } \\
\hline 302 & 17.769 & 15.075 & 36.556 \\
\hline 308 & 17.448 & 15.009 & 35.919 \\
\hline \multicolumn{4}{|l|}{ Toro granite gneiss } \\
\hline 142 & 17.454 & 1.552 & 41.897 \\
\hline 143 & 17.032 & 15.405 & 39.853 \\
\hline Toro migmatite & 18.805 & 15.616 & 38.730 \\
\hline \multicolumn{4}{|l|}{ Toro granites } \\
\hline 123 & 18.083 & 15.605 & 38.520 \\
\hline 125 & 18.009 & 15.598 & 37.931 \\
\hline 127 & 17.720 & 15.606 & 39.832 \\
\hline 131 & 17.935 & 15.573 & 39.123 \\
\hline 132 & 17.713 & 15.551 & 38.661 \\
\hline 133 & 17.798 & 15.562 & 40.207 \\
\hline 135 & 18.179 & 15.828 & 39.228 \\
\hline Toro gabbro (120) & 17.803 & 15.578 & 37.988 \\
\hline \multicolumn{4}{|c|}{ Toro charnockitic diorites } \\
\hline 129 & 17.527 & 15.538 & 38.379 \\
\hline 130 & 17.654 & 15.556 & 38.630 \\
\hline 140 & 17.821 & 15.562 & 38.432 \\
\hline 141 & 17.827 & 15.572 & 38.460 \\
\hline 145 & 17.863 & 15.536 & 38.514 \\
\hline 136 & 17.946 & 15.566 & 38.764 \\
\hline 139 & 17.903 & 15.587 & 38.838 \\
\hline
\end{tabular}

\section{Discussion}

\subsection{Comparative Metallogenesis}

Since we are interested in both the nature of the lead source and the identification of probable metal source rocks, the data presented in Table 1 \& Table 2 give a comparison of ore-lead and rock-lead. The genetic and prospecting consequences are very obvious, particularly for the epigenetic hydrothermal deposits under study. However, we have decided to compare the ore-lead with the $\mathrm{Pb}$ isotopic composition in the feldspars, which unlike the host rock-lead, denotes a phase with low $\mathrm{U} / \mathrm{Pb}(\mu)$ and
$\mathrm{Th} / \mathrm{Pb}(\mathrm{W})$ ratios; whose isotopic composition will not continue to evolve. The galena samples from the $\mathrm{Pb}-\mathrm{Zn}$ deposits of Abakaliki and Zurak areas plot in the same field with feldspars of the Pan African granitoids (with $\mu$ varying from 9.65 to 10.30). They have a remarkable uniformly unradiogenic composition for their age, although the Zurak group is slightly more radiogenic than the Abakaliki set. This places the deposits in the lower crustal geotectonic environment (Figure 7) of Zartman and Doe (1981), indicating a source of much lower $\mu$. In contrast, mineral extracts from the northwestern Nigeria gold deposits plot distinctively in the upper crustal geotectonic field typical of sources enriched in $\mathrm{U} / \mathrm{Pb}$ and $\mathrm{Th} / \mathrm{Pb}$. This is a clear indication of larger upper crustal reservoir with much higher $\mu$. The pyrite samples from Malele and Tsohon Birnin Gwari are expectedly more radiogenic than the bulk galena/chalcopyrite from Gurmana and the Malele galena extracts. Even taking the galena sample, often taken as representative of their gold deposits (Ayuso et al., 2005), the northwestern Nigeria gold deposits must have derived from highly radiogenic sources as shown in both the uranogenic and thorigenic diagrams (Figure 4 to Figure 7). Examples of geologically related but dissimilar lead-isotope provinces have been identified in the galena-bearing ore deposits of southwestern New Mexico (Stacey \& Hedlund, 1983) and western and central Europe (Koeppel, 1984).

Table 2. $\mathrm{Pb}$ isotope composition of mineral extracts from various Nigeria geological terrains. ML are data from Maurin et Lancelot, 1987

\begin{tabular}{|c|c|c|c|}
\hline Sample (NG) & ${ }^{206} \mathrm{~Pb} /{ }^{204} \mathrm{~Pb}$ & ${ }^{207} \mathrm{~Pb} /{ }^{204} \mathrm{~Pb}$ & ${ }^{208} \mathrm{~Pb} /{ }^{204} \mathrm{~Pb}$ \\
\hline \multicolumn{4}{|l|}{ K-feldspars } \\
\hline Kaduna gneiss & 15.825 & 14.863 & 35.732 \\
\hline Toro granite & 17.420 & 15.620 & 37.950 \\
\hline Toro charnockitic diorite & 16.890 & 15.510 & 37.880 \\
\hline Bauchi monzonite & 17.420 & 15.560 & 37.770 \\
\hline Jada granite & 17.640 & 15.603 & 37.708 \\
\hline Jada granite & 17.629 & 15.601 & \\
\hline Jalingo granite & 17.887 & 15.631 & 38.072 \\
\hline Mika granite & 17.796 & 15.569 & 37.848 \\
\hline \multicolumn{4}{|l|}{ NW Nigeria goldfields } \\
\hline Tsohon B/Gwari pyrite & 19.880 & 16.980 & 41.050 \\
\hline Malele pyrite & 19.930 & 16.960 & 41.090 \\
\hline Malele galena & 19.300 & 16.090 & 39.050 \\
\hline Gurmawa galena/chalcopyrite & 19.940 & 16.770 & 40.220 \\
\hline \multicolumn{4}{|l|}{ GALENA (Abakaliki) ML } \\
\hline 1 & 17.979 & 15.574 & 38.337 \\
\hline 2 & 17.966 & 15.561 & 38.287 \\
\hline 3 & 17.996 & 15.589 & 38.384 \\
\hline 4 & 18.001 & 15.599 & 38.413 \\
\hline 5 & 17.992 & 15.592 & 38.387 \\
\hline 6 & 17.982 & 15.591 & 38.394 \\
\hline \multicolumn{4}{|l|}{ GALENA (Zurak) ML } \\
\hline 1 & 18.074 & 15.633 & 38.473 \\
\hline 2 & 18.113 & 15.654 & 38.580 \\
\hline 3 & 18.085 & 15.638 & 38.504 \\
\hline 4 & 18.132 & 15.670 & 38.634 \\
\hline 5 & 18.133 & 15.682 & 38.673 \\
\hline 6 & 18.094 & 15.662 & 38.575 \\
\hline
\end{tabular}




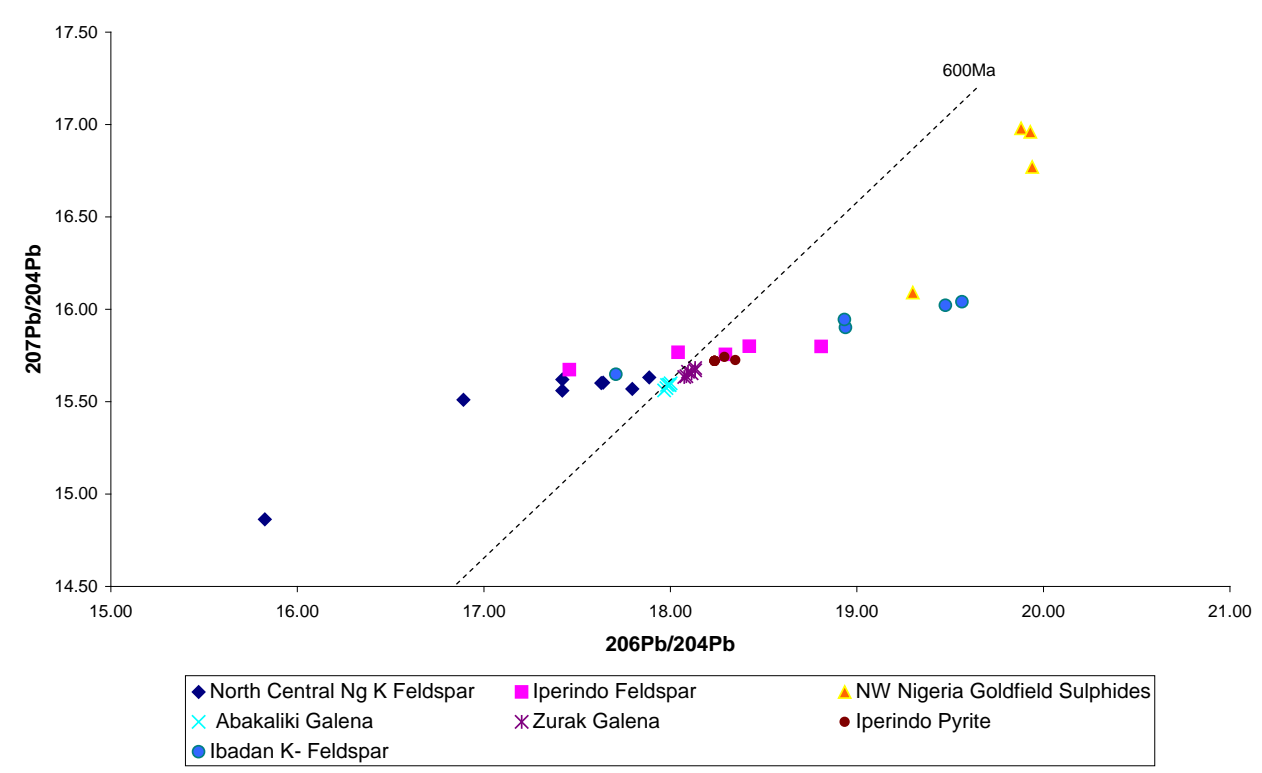

Figure 5a. ${ }^{207} \mathrm{~Pb} /{ }^{204} \mathrm{~Pb}$ vs ${ }^{206} \mathrm{~Pb} /{ }^{204} \mathrm{~Pb}$ of various mineral extracts in Nigeria with the 600 Ma reference isochron

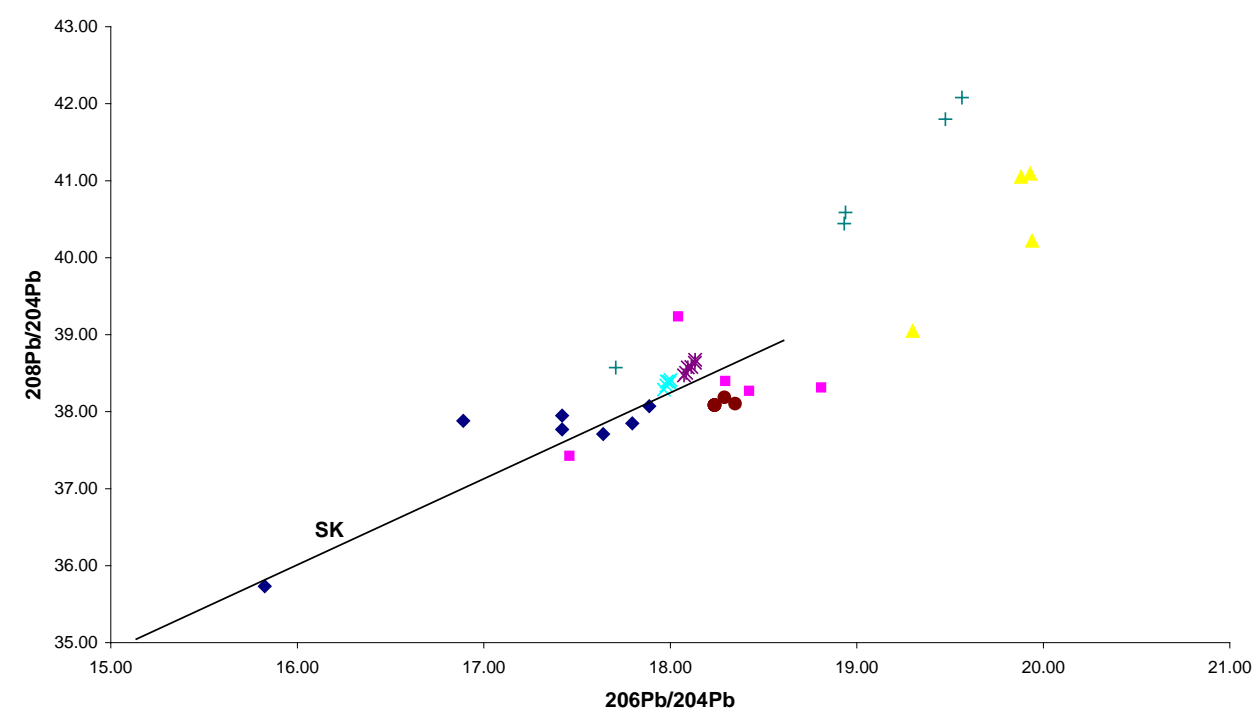

$\bullet$ K-Feldspar $\backsim$ Iperindo Feldspar $\triangle$ NW Nigeria Goldfields $\times$ Abakaliki Galena $*$ Zurak Galena $\bullet$ Iperindo Pyrite + Ibadan K-Feldspar

Figure 5b. ${ }^{208} \mathrm{~Pb} /{ }^{204} \mathrm{~Pb} \mathrm{vs}{ }^{206} \mathrm{~Pb} /{ }^{204} \mathrm{~Pb}$ of various mineral extracts in Nigeria with the average growth curve of Stacey \& Kramers, SK (1975)

\subsection{Constraints on Mineralizations}

Sulphide ores containing galena, sphalerite, pyrite, and chalcopyrite that commonly preserve the initial, primitive isotopic composition of the ore fluid occur in both Proterozoic metasedimentary rocks of the Nigerian schist belts and in Cretaceous sediments of the Benue Trough. We infer the provenance of ore metals in precious (gold) and base (lead-zinc) metal deposits from lead isotope data from the Proterozoic schist belts and the Cretaceous of the Benue Trough. Our data on sulphides (Table 1 \& Table 2) from Proterozoic goldfields of NW Nigeria show that their $\mathrm{Pb}$ compositions are much more radiogenic $\left({ }^{206} \mathrm{~Pb} /{ }^{204} \mathrm{~Pb}=19.30-19.94, \quad{ }^{207} \mathrm{~Pb} /{ }^{204} \mathrm{~Pb}=16.09-\quad 16.98\right.$, $\left.{ }^{208} \mathrm{~Pb} /{ }^{204} \mathrm{~Pb}=39.05-41.09\right)$ than those of K-feldspars from Pan African granitoids (Dada et al., 1995). This precludes the establishment of a direct genetic connection with the Pan African ganitoids. In comparison, pyrite from Iperindo goldfield in southwestern Nigeria have less radiogenic $\mathrm{Pb}$ composition $\left({ }^{206} \mathrm{~Pb} /{ }^{204} \mathrm{~Pb}=18.24-18.35\right.$, $\left.{ }^{207} \mathrm{~Pb} /{ }^{204} \mathrm{~Pb}=15.72-15.74,{ }^{208} \mathrm{~Pb} /{ }^{204} \mathrm{~Pb}=38.09-38.18\right)$. On the other hand, $\mathrm{Pb}$ isotope compositions of sulphides from the younger Cretaceous $\mathrm{Pb}-\mathrm{Zn}$ mineralization in the Benue Trough are even more significantly unradiogenic $\left({ }^{206} \mathrm{~Pb} /{ }^{204} \mathrm{~Pb}=17.98-18.13, \quad{ }^{207} \mathrm{~Pb} /{ }^{204} \mathrm{~Pb}=15.56-15.68\right.$, $\left.{ }^{208} \mathrm{~Pb} /{ }^{204} \mathrm{~Pb}=38.29-38.67\right)$ and compare with K-feldspars from Pan African granitoids (Maurin \& Lancelot, 1987). This led the authors to conclude for lead derived from a source strongly depleted in uranium such as detrital feldspars eroded from basement of Pan African age. The remarkable difference in isotopic compositions of the diachronous deposits cannot be explained by their age differences alone. In fact, crustal influences generally increase in younger ore associations (Bielichi \& Tischendorf, 1991) in many geological settings and it would appear more logical for Cretaceous mineralizations to contain more radiogenic $\mathrm{Pb}$ than those of the Proterozoic. The nature of the sources for the deposits and 
probably the character of the ore-forming processes require further elucidation. While mineralizing fluids were mostly derived from devolatilization of the Pan African collisional upper crustal slabs, the higher radiogenic character of the lead in sulphides of the goldfields would suggest a source of upper crustal affinity. This reinforces the stable isotope $\left({ }^{34} \mathrm{~S},{ }^{13} \mathrm{C},{ }^{18} \mathrm{O}\right)$ evidence for an upper crustal reservoir for the metals (Garba, 2000). Available U-Pb, Sm-Nd and Rb-Sr studies have revealed that NW Nigeria is underlain by Archaean basement (Bruguier et al, 1994, Dada, 1998) and their metasedimentary rocks contain a high proportion of Archaean-derived material. Such involvement of older rocks as source rocks for gold in Nigeria that was subsequently implicated in the Pan African thermotectonic event and mineralization is not in doubt.

\subsection{Tectonic Environments and Implications for Exploration}

Figure 6 \& Figure 7 show the distribution of isotopic composition values (Table 1 \& Table 2) in the curves for average $\mathrm{Pb}$ isotope evolution in the four Plumbotectonic domains of Zartman \& Doe (1981). It is evident that the sulphides from northwestern goldfields and the $\mathrm{K}$ feldspars from Ibadan aplites have a large component of ancient upper crustal material in the make-up of their rocks and mineralization; and rocks of Archaean age have been reported in both areas (Oversby, 1975; Bruguier et al, 1994, Dada, 1998). Further south in the southwestern Iperindo gold district, the data plot well below those of the NW goldfields and therefore indicates a much smaller involvement of older sialic material. The Iperindo sulphides plot below the Stacey and Kramers (1975) curve (SK) in Figure 5b and since the SK curve corresponds to the average orogene curve of Zartman \& Doe, they can at best be regarded as haven derived from a mixture between upper mantle and crustal leads.

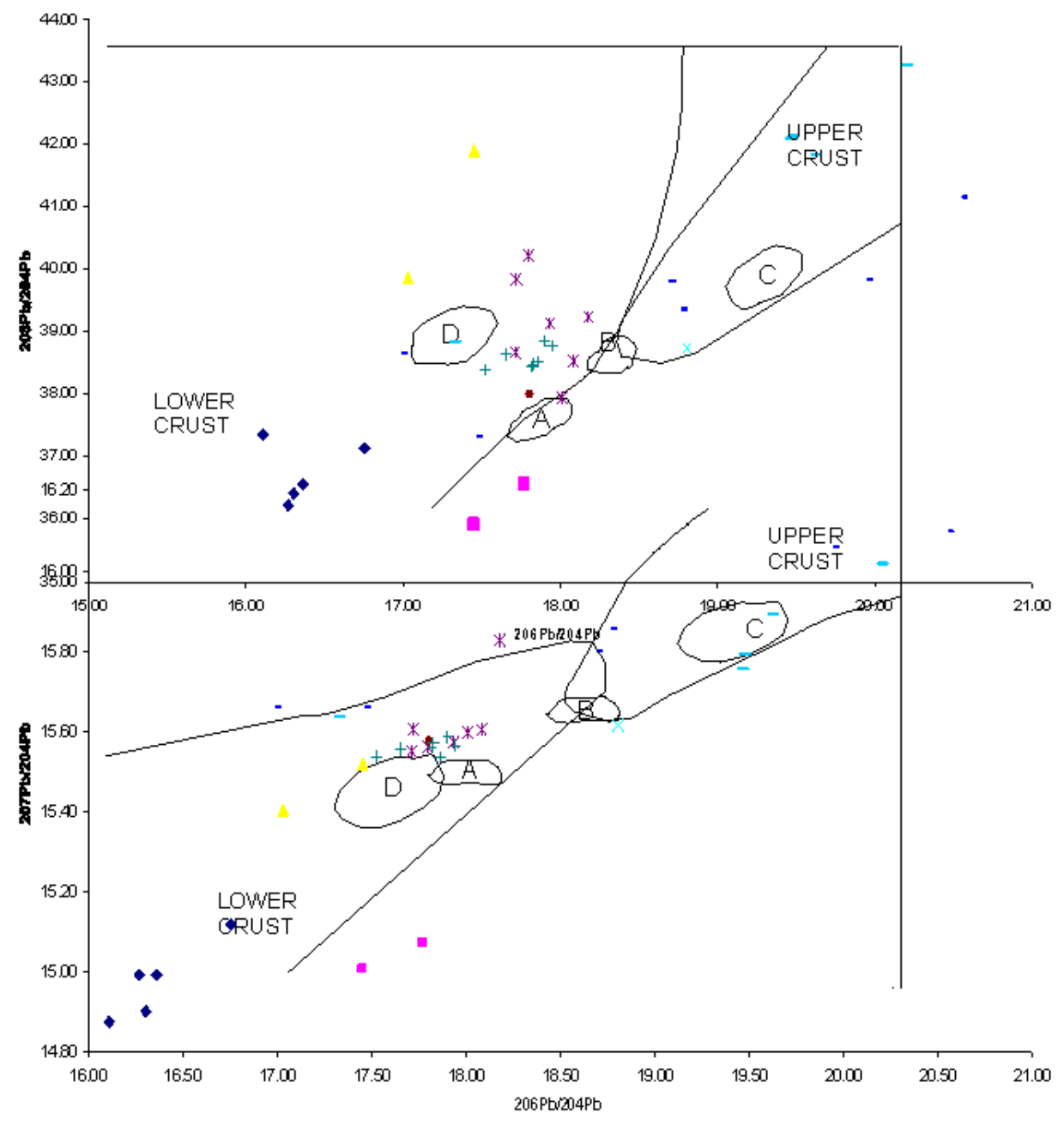

Figure 6. Plot of $\mathrm{Pb}$ isotopic composition of various rocks as in Figure 4. in the global geotectonic environments (Zartman \& Doe, 1981). A=mantle, $\mathrm{B}=$ orogen, $\mathrm{C}=$ upper crust, $\mathrm{D}=$ lower crust

Data from the galena samples from the Abakaliki and Zurak Pb-Zn mineralization indicate a much smaller older basement component. The assertion of Maurin \& Lancelot (1987) is corroborated by the isotopic evidence of Dada et al. (1995) and the contrasting evidence on Figure 7 that indicate upper mantle origin of subsequent evolution in the lower crust, without significant contribution from Archaean sources. Plutonic rocks responsible for mineralization in several geological terrains have been shown to have similar lead isotopic composition to that of the least sulphides in such regions (Stacey \& Hedlund, 1983); with the consequence that the least radiogenic leads are often favourable indicators for large ore deposits (Doe \& Stacey, 1974; Zartman, 1974). Exploration in Nigeria should therefore target and emphasize such near-source deposits of low radiogenic lead where erosion has not removed significant sedimentary and metasedimentary cover rocks. 


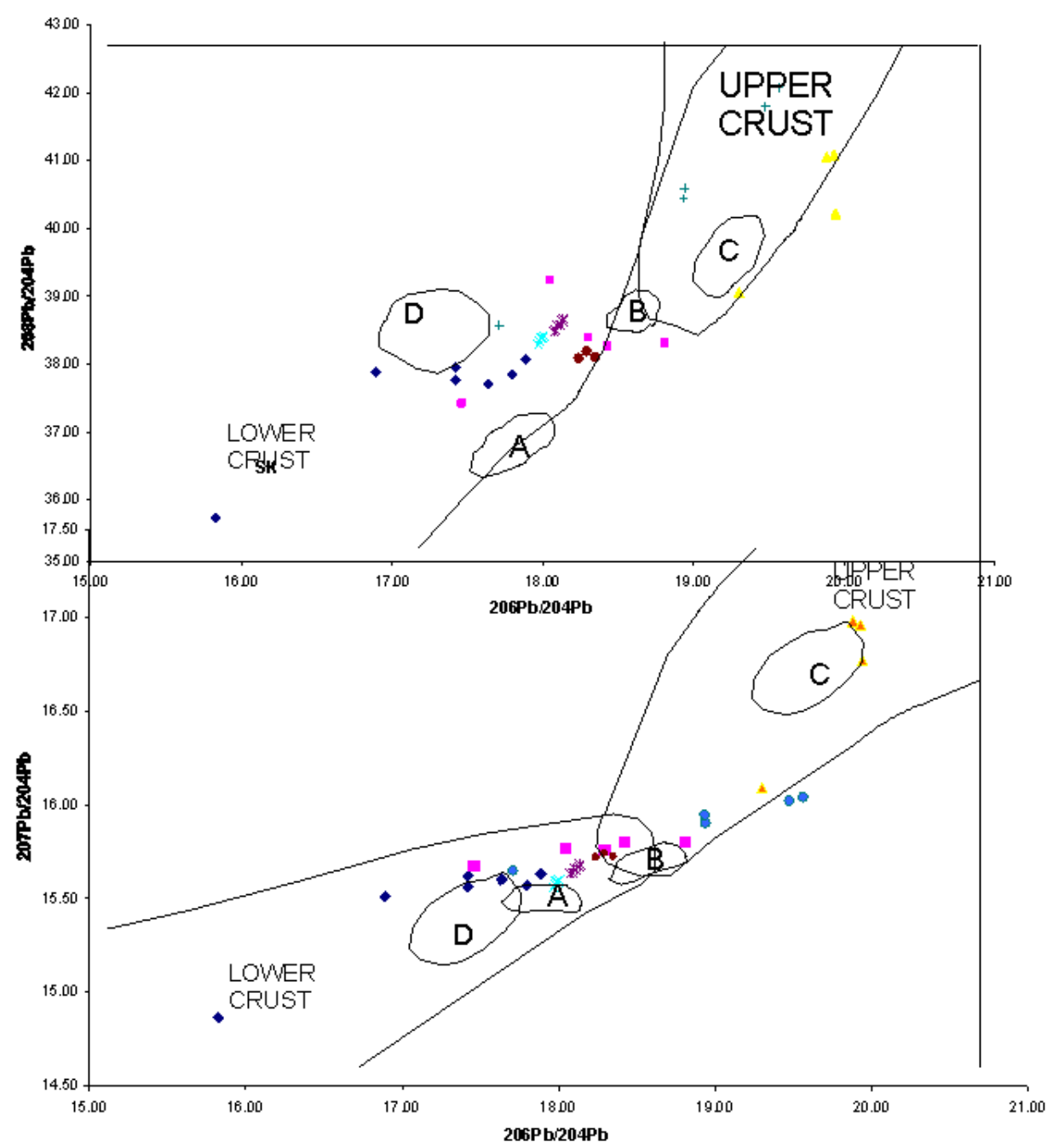

Figure 7. Plot of $\mathrm{Pb}$ isotopic composition of mineralisation as in Figure 5 in the global geotectonic environments (Zartman \& Doe, 1981). A=mantle, $\mathrm{B}=$ orogen, $\mathrm{C}=$ upper crust, $\mathrm{D}=$ lower crust

\section{Conclusions}

The development and evolution of the Nigerian crust from Archaean took place in several stages with the reworking of the older crust throughout the Proterozoic. Existing Sm-Nd, U-Pb, Rb-Sr and Pb-Pb data (Dada, 1998, 2008) indicate that a significant greater component of older material was incorporated into the metasedimetary pile in the western half of the country than into the eastern part during ancient subduction processes. Unradiogenic sources in the mantle but preferably in the lower crust have been inferred for the formation of Pan-African granitoids (Dada et al., 1995); and represent the most probable source reservoir for the less radiogenic Mesozoic $\mathrm{Pb}-\mathrm{Zn}$ mineralization in the Benue Trough (Maurin \& Lancelot, 1987). The reworked late Pan African pelites and phyllites of the upper crustal Younger Metasedimentary suite, that host the mineralized veinquartz, are hereby interpreted as the ultimate source for the more radiogenic $\mathrm{Pb}$ of the western auriferous terrains. The isotopic characteristics of mineralization in Nigeria therefore have no direct relationship with age of formation but to structural settings and geological history. $\mathrm{Pb}-\mathrm{Pb}$ isotope systematics suggests that metal sources are essentially from the crust implicated in well-defined structural discontinuities by hydrothermal processes during both the Pan African and Mesozoic. The correlation between radiogenic factor in $\mathrm{Pb}$ and size of deposit remains to be confirmed in the light of the low level of exploration activity.

\section{Acknowledgments}

Several people have contributed to this study, notably the Isotope Research groups at the University of Science and Technology (USTL), Montpellier and University of Paris 6 \& 7 (IPGP) as well as Nigerian colleagues, including AOO (UNAD) with whom we had useful and stimulating discussions.

\section{References}

[1] Annor AE (1995) U-Pb zircon age for Kabba-Okene granodiorite gneiss: implication for Nigeria's basement chronology. African Geoscience Review 2 101-105.

[2] Ayuso RA, Wooden JL, Foley NK, Seal RR, Sinha AK (2005) U$\mathrm{Pb}$ Zircon Ages and $\mathrm{Pb}$ Isotope Geochemistry of Gold Deposits in the Carolina Slate Belt of South Carolina. Economic Geology 100 no. 2; p. 225-252.

[3] Bielicki KH, Tischendorf G (1991) Lead isotope and Pb-Pb model age determinations of ores from Central Europe and their 
metallogenetic interpretation. Contributons to Mineralogy and Petrology 1064 440-461.

[4] Bruguier O, Dada S, Lancelot JR (1994) Early Archaean component ( $>3.5 \mathrm{Ga}$ ) within a 3.05 Ga orthogneiss from northern Nigeria: U-Pb zircon evidence. Earth and Planetary Science Letters 125 89-103.

[5] Caby R, Boesse M (2001) Pan African nappe system in southwest Nigeria: the Ife Ilesha schist belt. Journal of African Earth Sciences 33 211-225.

[6] Dada SS, Respaut JP (1989) La monzonite a fayalite de Bauchi (bauchite): Nouveau emoin d'ún magmatisme syntectonique panafricain au nord du Nigeria. Compte Rendus Academie des Sciences de Paris 309 (II) 887-892.

[7] Dada SS, Lancelot JR, Briqueu L (1989) Age and origin of the annular charnockitic complex at Toro, Northern Nigeria: U-Pb and Rb-Sr evidence. Journal of African Earth Sciences 92 227-234.

[8] Dada, S.S., Briqueu, L. Harms, U., Lancelot, J.R. \& Matheis, G. (1995) Charnockitic and monzonitic Pan-African series from north central Nigeria: Trace-element and $\mathrm{Nd}, \mathrm{Sr}, \mathrm{Pb}$ isotope constraints on their petrogenesis. Chemical Geology (Isotope Geoscience) 124 233-252.

[9] Dada S S (1998) Crust-forming ages and Proterozoic crustal evolution in Nigeria: a reappraisal of current interpretations. Precambrian Research 87 65-74.

[10] Dada SS (2008) Proterozoic evolution of the Nigeria-Boborema province. Geological Society, London, Special Publications 294 121-136.

[11] Doe BR, Stacey JS (1974) The application of lead isotopes to the problem of ore genesis and ore prospect evaluation: Economic Geology 69 757-776.

[12] Garba I (2000) Origin of Pan-African mesothermal gold mineralization of Bin Yauri, Nigeria. Journal of African Earth Sciences 312 433-449.

[13] Grant NK (1970) Geochemistry of Precambrain basement rocks from Ibadan, southwestern Nigeria. Earth \& Planetary Science Letters 10 29-38.

[14] Jardin De Sa EF, Wacedo WH, Legrand JM, Mcreath L, Galindo A, SA, JM (1987) Proterozoic granitoids in a polycylic setting; the Serido region, northeast Brazil; In: International Symposium on Granites and Associated Mineralization, Salvador, Brazil, Extended Abstracts 103-110.

[15] Koeppel V (1984) Lead Isotopes as Tracers of the Origin of Metals in Ore Deposits and of the Evolution of Continental Crust: Examples from Western and Central Europe. Proceedings of the $27^{\text {th }}$ International Geological Congress in Metallogenesis and Mineral Ore Deposits 12 53-82.

[16] Maurin JC, Lancelot JR (1987) Origine des mineralisations de PbZn de la Vallee de la Benoue (Nigeria) d'apres la composition en $\mathrm{Pb}$ des galenes de l'encaissant. Mineralium Deposita 22 99-108.

[17] Neves PS, Bruguier O, Vauchez A, Bosch D, Rangel Da Silva JS, Mariano G (2006) Timing of crust formation, deposition of supracrustal sequences, and Transamazonian and Brasiliano metamorphism in the East Pernambuco belt (Borborema Province, NE Brazil): Implications for western Gondwana Assembly. Precambrian Research 149 197-216.

[18] Neves SP, Bruguier O, Rangel Da Silva, JM, Bosch D, Alcantara VC, Lima CM (2009) The age distributions of detrital zircons in metasedimentary sequences in eastern Borborema Province (NE
Brazil): Evidence for intracontinental sedimentation or orogenesis? Precambrian Research 175 187-205.

[19] Offodile ME (1980) A mineral survey of the Cretaceous of the Benue Valley, Nigeria. Cretaceous Research 1 101-124.

[20] Ogunleye PO, Ike EC, Garba I (2003) Geochemistry of the niobium-rich arfvedsonite granites of the northern Nigerian anorogenic ring-complexes. Annual Conference of the Nigerian Mining \& Geosciences Society, Itakpe, 39.

[21] Oversby VM (1975) Lead isotopic study of aplites from the Precambrium basement complex rocks near Ibadan, Southwest Nigeria. Earth and Planetary Science Letters, 27, 177-180.

[22] Oyinloye AO (2006) Metalogenesis of the lode gold deposit in Ilesha area of southwestern Nigeria: inferences from lead isotope systematics. Pakistan Journal of Scientific \& Industrial Research 9 1 1-11.

[23] Rahaman MA, Lancelot JR (1984) Continental crust evolution in SW Nigeria: Constraints from U/Pb dating of pre-Pan-African gneisses. In: Rapport dáctivité 1980-1984. Document Travaux Centre Geologie et Geophysique, Montpellier, II 441.

[24] Rahaman MA and Emofurieta WO (1983) The potassic granites of Igbeti area: Further evidence of the polycyclic evolution of the Pan-African Belt in Southwestern Nigeria. Precambrian Research 22 75-92.

[25] Rahaman M.A, Tubosun IA, Lancelot, JR (1991) U-Pb geochonology of potassic syenites from southwestern Nigeria and the timing of deformational events during the Pan-African orogeny. Journal of African Earth Sciences 13 387-395.

[26] Rudnick RL, Goldstein SL (1990) The Pb isotope compositions of lower crustal xenoliths and the evolution of lower crustal $\mathrm{Pb}$. Earth Planetary Science Letters 98 192-207.

[27] Stacey JS, Hedlund DC (1983) Lead-isotopic compositions of diverse igneous rocks and ore deposits from southwestern New Mexico and their implications for early Proterozoic crustal evolution in the western United States. Geological Society of America Bulletin 94 43-57.

[28] Stacey JS, Kramers JD (1975) Approximation of terrestrial lead isotope evolution by a two-stage model. Earth Planetary Science Letters. 26 206-221.

[29] Tubosun IA, Lancelot JR, Rahaman MA, Ocan O (1984) U-Pb Panafrican ages of two charnockite-granite association from southwestern Nigerian. Contributions to Mineralogy and Petrology 88 188-195.

[30] Van Schmus WR, Brito Neves BB et al. (2003) The Serido Group of NE Brazil, a late Neoproterozoic pre-to syn-collisional basin in West Gondwana: insights from SHRIMP U-Pb detrital zircon ages and Sm-Nd crustal residence $\left(\mathrm{T}_{\mathrm{DM}}\right)$ ages. Precambrian Research 127 287-327.

[31] Zartman RE (1974) Lead isotope provinces in the Cordilleran of the western United States and their geology significance. Economic Geology 69 901-942.

[32] Zartman RE, Doe BR (1981) Plumbotectonics. The model Tectonophysics 75 135-162. 